\title{
Optimizing the conversion of cow dung to bio-energy under anaerobic condition by varying the organic loading rate (OLR) using proto-types of Chinese fixed dome bioreactor (CFDB)
}

\author{
${ }^{1}$ Maduekeh, E. C.; ${ }^{2}$ Onwurah, I. N. E.; ${ }^{3}$ Okoye, A. C.; ${ }^{4}$ Madueke, C. O., \\ ${ }^{5}$ Ukonu, C. U., ${ }^{6}$ Okafor, E. C. and ${ }^{7}$ Ojeh, O. \\ ${ }^{1}$ Biochemistry Unit, Department of Science Laboratory Technology, Federal College of Agriculture, Ishiagu, \\ Ivo LGA, Ebonyi State, Nigeria; \\ ${ }^{2}$ Environmental Biotechnology and Toxicology Unit, Department of Biochemistry, University of Nigeria, \\ Nsukka, Enugu State, Nigeria; \\ ${ }^{3}$ Department of Environmental Science, Nnamdi Azikiwe University, Awka, Anambra State, Nigeria; \\ ${ }^{4}$ Agronomy Unit, Lower Anambra Irrigation Project, Omor, Anambra State, Nigeria; \\ ${ }^{5}$ Post Graduate Laboratory, Department of Biochemistry, Faculty of Biological Sciences, University of Nigeria, \\ Nsukka, Enugu State, Nigeria; \\ ${ }^{6}$ Department of Bio-Environmental Engineering Technology, Federal College of Agriculture, Ishiagu, Ivo LGA, \\ Ebonyi State, Nigeria; and \\ ${ }^{7}$ Department of Biochemistry, Federal University Ndufu-Alike, Ikwo, Ebonyi State, Nigeria.
}

\begin{abstract}
Biomass technology is a technology which has great potentials in helping mankind surmounts some of the challenges of the $21^{\text {st }}$ century. These challenges include; waste management, inadequate energy and food security. However, it is facing a number of teething roadblocks, which include the fact that it is slow. A number of researchers in the field have observed that organic loading rate (OLR) affects biogas generation under anaerobic conditions. Hence, this study seeks to identify the optimum OLR for biogas generation. Six (6) fifty (50) kilogramme capacity prototypes of Chinese fixed dome bioreactor (CFDB), labelled 1 through 6, were used to investigate the effect of OLR on biogas generation. The physicochemical properties of the cow dung sample were determined. OLR of $163.50,81.75,54.50,40.38,32.70$ and $27.25 \mathrm{~g}$ TS per liter of slurry were then respectively charged into the bioreactors. Bioreactor operating conditions of $\mathrm{pH}$, temperature and daily gas production were subsequently monitored over the hydraulic retention time (HRT). HRT was 25 days. At the end of the HRT, bioreactor 6 had the best biogas yield of $4.81 \pm 1.54$, while bioreactor 4 and 5 also had good gas yields of $3.51 \pm 0.5$ and $3.43 \pm 1.66$ respectively. The result obtained suggests that in areas experiencing water scarcity, OLR of $40.38 \mathrm{~g}$ TS per liter of slurry of Bioreactor 4 can be adopted.
\end{abstract}

Key words: Anaerobic degradation, Bio-energy, Biomass technology and Organic loading rate

\section{Introduction}

Increase in global healthcare and life expectancy witnessed from the turn of the $20^{\text {th }}$ century as a result of advances in science and technology, although a very welcome development, increased the challenges facing mankind. The root of this challenge is "population explosion". This has led to greater demand for food and energy, hence, placing enormous challenge on the sustainable use of available resources. In mans' quest to meet this two needs, he has triggered a chain reaction of environmental hazards which are beginning to hunt his existence on earth. Precisely, reliance on fossil fuels - which are finite in supply - to meet the energy needs of this teeming population created myriads of challenges ranging from increase in green house gases, to depletion of ozone layer, global warming, melting of polar ice and flooding, to mention but a few.

On the other hand, in order to boost food production, animal husbandry is an area of agriculture which has seen steady growth, with cattle production receiving a fair share of that growth. This desired increase in food production did not come without attendant increase in waste production as is evident from the increase in cattle manure waste. Solid cattle manure can create several problems such as odor, runoff, and potential pathogen contamination. Furthermore, liquid manure in ponds releases considerable amounts of uncontrolled methane $\left(\mathrm{CH}_{4}\right)$ gas into the atmosphere. In the United States for instance, the third greatest source of methane emission is agriculture, emitting approximately one-quarter of total national $\mathrm{CH}_{4}$ emission [1]. According to $\mathrm{Al}$ Seadi et al. [2], methane gas is 23 times more active as a greenhouse gas (GHG) than carbon dioxide. Hence, this uncontrolled methane emission as a result of these agricultural activities contributes enormously to global warming with its attendant environmental consequences. 
Fig. 1 illustrates our present predicament. Precisely, fossil fuel formed as result of many years of accumulation of organic materials in the earth is burnt to meet our energy needs and in the process, GHGs are released into the atmosphere. Plants serving as cleaners of the environment use one of these GHGs $-\mathrm{CO}_{2}-$ in the presence of light from sun and water to make organic materials which all living things depend on. As a result of the activities of these living things, "organic wastes" are produced which if not efficiently disposed or utilized leads to further release of GHGs into the atmosphere, pollution of underground water, blocking of water ways, etc, with far reaching consequences.

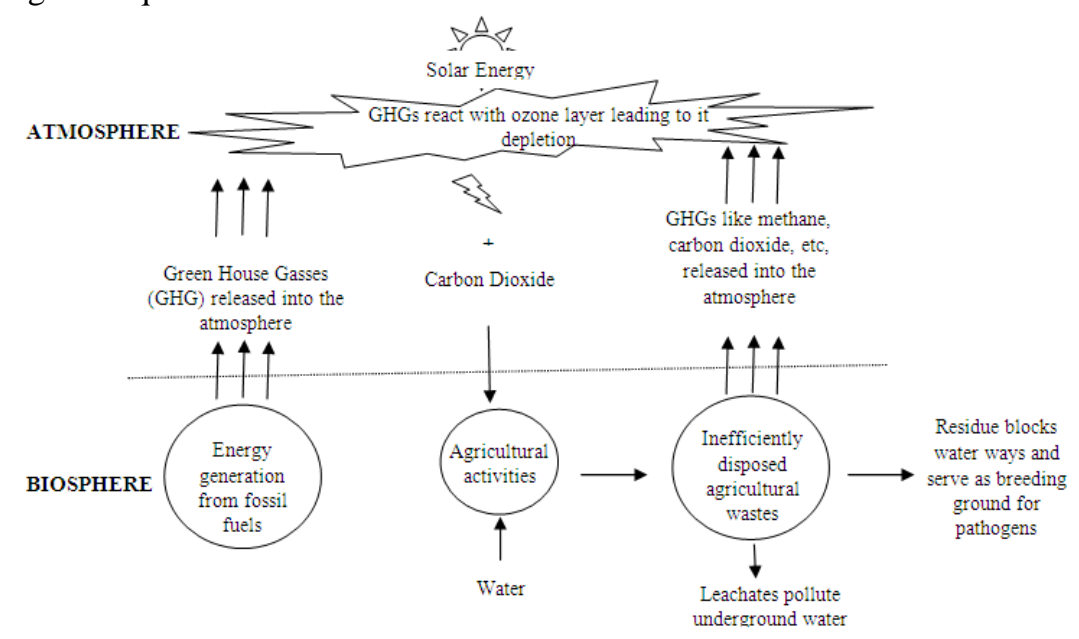

Fig. 1: The impact of dependency on fossil fuels and inefficiently disposed agricultural wastes on the environment

The building of a sustainable society will require reduction of dependency on fossil fuels and lowering of the amount of pollution that is generated [3]. There is also the need for energy recycle and re-use; particularly, by closing the cycle of food production from agricultural activities and waste generated from such activities as is depicted in Figure 1. Anaerobic biomass technology offers this opportunity.

It is the process by which biomass is fermented by subjecting it to anaerobic condition in specialized equipments known as digesters. The degradation pathways to produce bio-energy in the form of methane is summarized with a 4-stage model shown in Fig. 2.

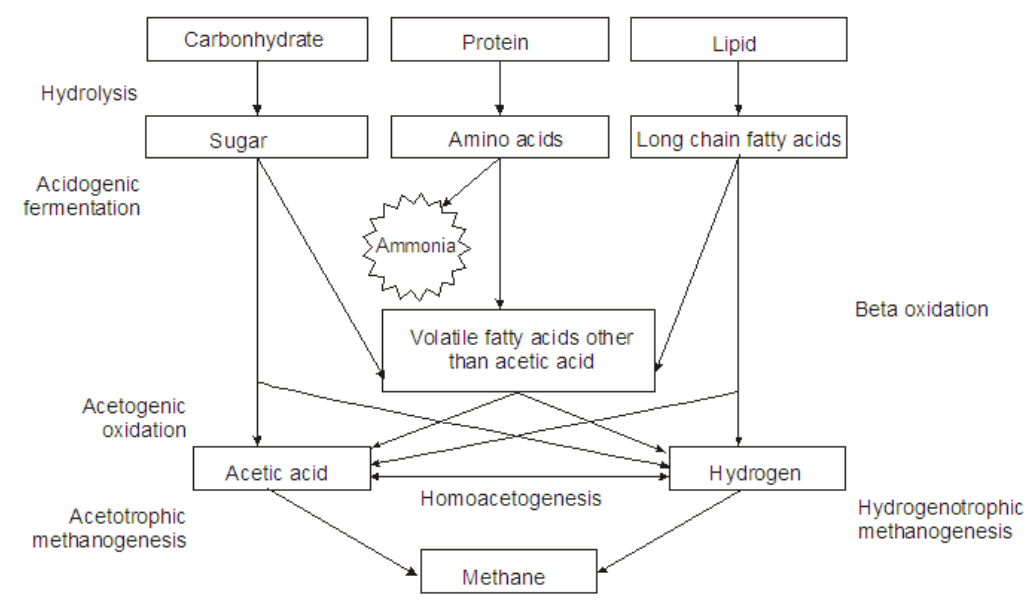

Fig. 2: Anaerobic pathways in anaerobic degradation [4].

Anaerobic digestion is widely studied because it can produce renewable energy, reduce organic and pathogen content, and create a stable residual waste that can be used as soil fertilizer [5][6][7][8]. One of the challenges facing the use of anaerobic biomass technology is the fact that it is slow [9].

Since the process of digestion is a complex process involving the activities of microbes, some conditions ought to be maintained to ensure optimum gas production [10]. Angenent et al. [11]; Kelleher et al. [12] ; Speece [13] and Munch et al. [14] have all demonstrated through research that alterations in OLR has significant effect on anaerobic degradation efficiency. Hence the aim of this study is to identify the optimum organic loading rate for bio-energy recovery from cattle manure using anaerobic biomass technology. 
Materials

\section{Materials And Method}

The bioreactors/ digesters used for this study are the fifty (50) kilogramme capacity prototype of Chinese fixed dome bioreactor (CFDB) made with galvanized steel (gauge 18) shown in Fig. 3B. These bioreactors were located at the National Center for Energy Research and Development (NCERD), University of Nigeria, Nsukka. Cow dung was collected from Nsukka abattoir in new community market Ikpa in Nsukka, Enugu State, Nigeria. Nsukka is located at Lattitude $6.8^{\circ} \mathrm{N}$ and Longitude $7.29^{\circ} \mathrm{E}$ [10]. Other materials used include; thermometer (-10 to 110 graduation), and digital $\mathrm{pH}$ meter.

Fig. 3 (A) is a picture revealing the challenge posed by cow dung to environment and health of the people; while Fig. 3 (B) is a picture of the digesters used in this study.
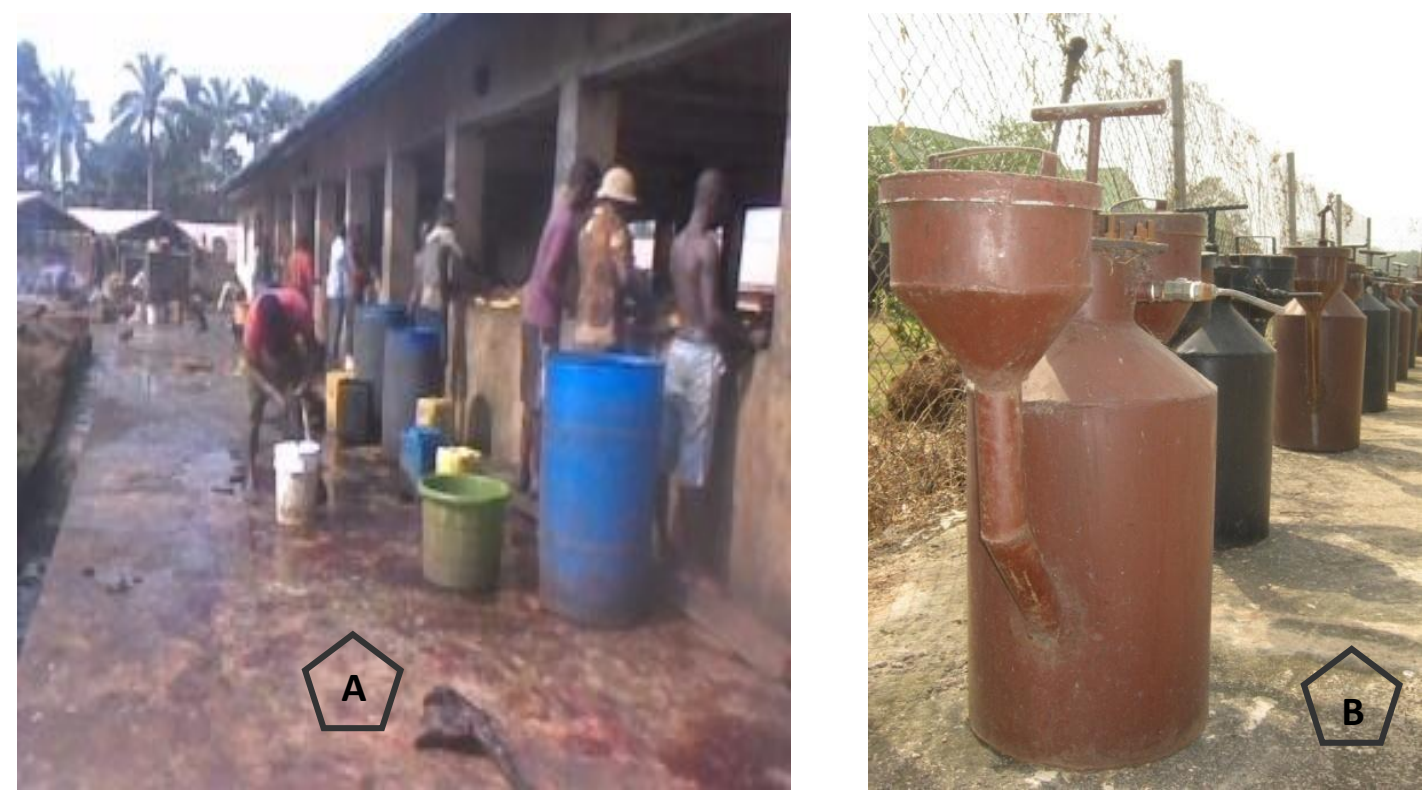

Fig. 3: (A) Cow dung washed into drainage at Nsukka abattoir; (B) Fifty kilogramme capacity prototype of Chinese fixed dome bioreactor located at the NCERD used for this study.

\section{Method}

\section{Experimental design}

\section{Procedure}

Six appropriately labeled fifty (50) kilogramme capacity prototype CFDBs were used.

Appropriate quantities of cow dung were weighed out in the respective ratios and mixed with the commensurate quantity of water in a spacious plastic trough as indicated in Table 1 . The reaction mixtures were then charged into the appropriately labeled fifty kilogramme capacity prototype of Chinese fixed dome bioreactor. All bioreactors were seventy five (75) percent filled with the slurry leaving twenty five (25) percent headspace for gas collection. Subsequently, all nuts and the bioreactor tap were tightly screwed to exclude air. Throughout the Hydraulic Retention Time (HRT), the bioreactor contents were stirred daily at 50 turns per minute to ensure homogenous dispersion of the substrate and microbes in the mixture.

Table 1: Ratio and actual weight of samples charged into the various bioreactor in

\begin{tabular}{ccc}
\hline & Ratio (WS:WT) & Actual Weight of Samples (Kg) \\
\hline 1 & $1: 0^{*}$ & $37.50: 0.00$ \\
2 & $1: 1$ & $18.75: 18.75$ \\
3 & $1: 2$ & $12.50: 25.00$ \\
4 & $1: 3$ & $9.38: 28.13$ \\
5 & $1: 4$ & $7.50: 30.00$ \\
6 & $1: 5$ & $6.25: 31.25$ \\
\hline
\end{tabular}

Six (6) appropriately labeled fifty (50) kilogramme capacity CFDBs were used

* Bioreactor 1 served as the control as no water was added to the sample. 25 days Hydraulic Retention Time (HRT) 


\section{Parameters monitored}

Ash, moisture and fiber content of the waste was determined using AOAC method [15] while fat content, crude protein and nitrogen content of the wastes were determined using soxlet extraction and micro Kjeldahl methods as described by Pearson [16]. Carbon content was determined using the method described by Walkey and Black [17]. Total solids (TS) and volatile solids (VS) were determined using Meynell [18] method. All reagent used were of analytical grade.

\section{Data analysis}

The data obtained was analyzed using one way analysis of variance at 95 per cent confidence interval $(\mathrm{p} \leq 0.05)$ with Statistical Package for Social Sciences version 16. The significant means were separated using Duncan Multiple Correlation.

\section{Results}

The result of the physicochemical analysis of the of cow dung (CD) is shown in Table 2 while Table 3 shows the result of the bioreactor operating conditions of $\mathrm{pH}$, temperature, organic loading and average daily gas yield.

Table 2: Physicochemical properties of cow dung and saw dust used

\begin{tabular}{lc}
\hline Parameter & Cow dung \\
\hline Moisture (\%) & 83.55 \\
Ash (\%) & 2.70 \\
Fibre (\%) & 0.04 \\
Crude nitrogen (\%) & 0.25 \\
Crude protein (\%) & 1.62 \\
Fat content (\%) & 0.15 \\
Total solids (\%) & 16.35 \\
Carbon content (\%) & 7.30 \\
Volatile solids (\%) & 13.65 \\
Carbohydrate (\%) & 11.94 \\
C:N & 29.20 \\
\hline
\end{tabular}

Table 3: Bioreactor operating conditions of $\mathrm{pH}$, temperature, organic loading and average daily gas yield

\begin{tabular}{|c|c|c|c|c|c|c|}
\hline & $\begin{array}{l}\text { Bioreactor } \\
(1: 0)^{*} \\
\end{array}$ & $\begin{array}{l}\text { Bioreactor } 2 \\
(1: 1)^{*}\end{array}$ & $\begin{array}{l}\text { Bioreactor } 3 \\
(1: 2)^{*}\end{array}$ & $\begin{array}{l}\text { Bioreactor } 4 \\
(1: 3)^{*}\end{array}$ & $\begin{array}{l}\text { Bioreactor } \\
(1: 4)^{*} \\
\end{array}$ & $\begin{array}{l}\text { Bioreactor } \\
(1: 5)^{*} \\
\end{array}$ \\
\hline $\begin{array}{l}\text { Total volume of cow dung (kg) on } \\
\text { which calculations are based }\end{array}$ & 6.25 & 6.25 & 6.25 & 6.25 & 6.25 & 6.25 \\
\hline Average daily slurry pH \pm SEM & $8.21 \pm 0.68^{b}$ & $7.94 .37 \pm 0.76^{a}$ & $7.88 \pm 0.64^{\mathrm{ab}}$ & $7.72 \pm 0.41^{\mathrm{ab}}$ & $7.64 \pm 0.46^{\mathrm{a}}$ & $7.48 \pm 0.37^{\mathrm{a}}$ \\
\hline $\begin{array}{l}\text { Average daily slurry temperature } \\
\left({ }^{\circ} \mathrm{C}\right) \pm \text { SEM }\end{array}$ & $32.16 \pm 3.83^{\mathrm{a}}$ & $32.02 \pm 3.36^{\mathrm{a}}$ & $32.28 \pm 3.60^{\mathrm{a}}$ & $32.26 \pm 3.45^{\mathrm{a}}$ & $30.46 \pm 2.71^{\mathrm{a}}$ & $30.6 \pm 2.83^{\mathrm{a}}$ \\
\hline $\begin{array}{l}\text { Organic Loading } \\
\text { (g TS L of slurry) }\end{array}$ & 163.50 & 81.75 & 54.50 & 40.38 & 32.70 & 27.25 \\
\hline $\begin{array}{l}\text { Organic Loading } \\
\text { (g VS L of slurry) }\end{array}$ & 136.50 & 68.25 & 45.50 & 34.13 & 27.30 & 22.75 \\
\hline $\begin{array}{l}\text { (a) Average daily gas production } \\
\text { in liters at Standard } \\
\text { Temperature }\left(\mathrm{L} \mathrm{g}^{-1} \mathrm{VS}\right) \pm \mathrm{SEM}\end{array}$ & $0.46 \pm 0.32^{\mathrm{a}}$ & $0.96 \pm 0.75^{\mathrm{ab}}$ & $1.48 \pm 0.87^{\mathrm{b}}$ & $3.51 \pm 0.52^{\mathrm{c}}$ & $3.43 \pm 1.66^{\mathrm{c}}$ & $4.81 \pm 1.54^{(\mathrm{d})}$ \\
\hline
\end{tabular}

Means in the same row with the same letter(s) are not statistical significant $(\mathrm{p} \geq 0.05)$; Hydraulic Retention Time (HRT) was 25 days and average daily ambient temperature was $27.30 \pm 2.39{ }^{\circ} \mathrm{C}, \mathrm{n}=25$; *

Values in parenthesis are the ratio of cow dung to water in each reactor; (a) Values are normalized to STP. Values were significantly different from Bioreactor 1 to Bioreactor 6; (d) Optimal gas production, under the given conditions

\section{Discussion}

The result of the physicochemical analysis of the raw material, cow dung (CD), is shown in Table 2 and contains the indices of digester performance which according to Ogbeide [19] include TS and C: N ratio. Kanu [20] reported that although an influent with over $10 \%$ TS can be used without problem, a TS of $3-10 \%$ was optimum for efficient and effective anaerobic degradation of cow dung while Eze et al. (2008) stated that a 
TS of $5.0-7.5$ was optimum for biogas production. TS for the sample of CD (16.35\%) was above the maximum limit stipulated by both Kanu [20] and Eze et al. [21], as optimal for biodegradation. Although, the microbial population involved in anaerobic digestion require sufficient nutrient to grow and multiply of which a C: $\mathrm{N}$ ratio of about 20 - 30: 1 have been found to be optimal for biogas production [22] [23] thus indicating that the C: N ratio of the cow dung sample (29.2) favours the growth of the methanogenic microbes, the result of the TS suggests that some dilution is necessary. This is in support of the view of Dennis and Burke [24]. However, the result of the $\mathrm{C}: \mathrm{N}$ ratio suggests that cow dung is a good culture media for anaerobic biodegrading microbes. This view is supported by the findings of Eze et al [25].

Hence, since according to Kanu [20] and Eze et al. [21] TS loading play a vital role in biodegradation efficiency, there is the need to alter this characteristics of waste to ensure that the bioreactors operate at optimum TS loading. Waste characteristics can be altered by simple dilution [24]. According to Dennis and Burke [24], some dilution will reduce the concentration of certain constituents such as nitrogen and sulfur that produce products that are inhibitory to the anaerobic digestion process, stating precisely that, high solids digestion creates high concentrations of end products that inhibit anaerobic decomposition. Hence, dilution can have positive effects.

Therefore, analysis was carried out to determine the optimum waste to water ratio for degradation. The result of the bioreactor operating conditions of $\mathrm{pH}$, temperature, organic loading and daily gas production are shown in Table 3.

When the average slurry $\mathrm{pH}$ of the various bioreactor mixes were compared with the control using one way analysis of variance at $95 \%$ confidence interval, bioreactors 2 to 4 showed no statistically significant difference from the $\mathrm{pH}$ of the control while bioreactor 5 and 6 showed a statistical significant decrease in $\mathrm{pH}$. This decrease in $\mathrm{pH}$ observed could be as result of a favourable water ratio and hence organic loading which seemed to enhance the activities of the degrading organisms as is evident from the production of more acidic molecules probably including acetic acid thus pushing the $\mathrm{pH}$ down towards optimum. However, when bioreactor average slurry $\mathrm{pH}$ conditions were compared within the groups, they showed no statistically significant difference. The average daily slurry $\mathrm{pH}$ of all bioreactors fell within the $\mathrm{pH}$ range of $6.8-8.5$ reported by Dennis and Burke [24] as optimum for biodegradation while only bioreactors 4, 5 and 6 with average daily slurry $\mathrm{pH}$ of 7.72, 7.64 and 7.48 respectively fell within the range of optimum $\mathrm{pH}(6.5-7.8)$ suggested by US EPA (2001). The control (8.21), bioreactor 2 (7.94) and bioreactor 3 (7.94) had a pH that is greater than the upper limit of 7.8 suggested by US EPA [26].

The slurry temperature of the bioreactors which fell within the mesophillic range of $20^{\circ} \mathrm{C}$ to $40^{\circ} \mathrm{C}$ [27] when compared with the control and with each other showed no statistically significant difference. The implication of this is that the microbes strive to maintain the temperature of the bioreactors at a particular range which happen to be within the mesophillc range.

Gas production as shown in Table 3 when compared with the control which had a waste to water ratio of 1:0 with an OLR of $163.50(0.46 \pm 0.32)$, bioreactors 2 waste to water ratio 1:1 and OLR of $81.75(0.96 \pm$ $0.75)$ and bioreactor 3 which had a waste to water ratio $1: 2$ and OLR of $54.50 \mathrm{~g} \mathrm{TS} \mathrm{L}^{-1}$ of slurry $(1.48 \pm 0.87)$ respectively showed no statistically significant difference from the control while bioreactors 4 waste to water ratio 1:3 with OLR of $40.38(3.51 \pm 0.52)$, bioreactor 5 with waste to water ratio $1: 4$ and OLR of $32.70(3.42 \pm$ 1.66) and bioreactor 6 waste to water ratio of $1: 5$ and OLR of $27.25 \mathrm{~g} \mathrm{TS} \mathrm{L}^{-1}$ of slurry $(4.81 \pm 1.54)$ respectively showed a statistically significant increase in gas production. Bioreactor 4 and 5 when compared with each other showed no statistically significant difference while bioreactor 6 showed a statistically significant increase in gas production when compared with bioreactors 4 and 5. From the result, bioreactor 6 is optimal for gas production although bioreactors 4 and 5 also showed a good gas yield, this result did not disagree much with the water to waste ratio of 4:1 suggested by Eze et al. [25].

Looking at the TS content of these bioreactor mixes which is $40.38 \mathrm{~g} / \mathrm{L}$ of slurry $(4.038 \%), 32.70 \mathrm{~g} / \mathrm{L}$ of slurry $(3.270 \%)$ and $27.25 \mathrm{~g} / \mathrm{L}$ of slurry $(2.725 \%)$ for bioreactors 4,5 and 6 respectively they seem to fall below the lower limit of 5.0-7.5\% stipulated by Eze et al. [21] for optimum biogas production but bioreactor 4 and 5 were slightly higher than the lower limit of TS stipulated by Kanu [20] with bioreactor 6 being slightly lower than the stated lower limit. From the result obtained, for optimal degradation a TS content that is as close as possible to $3.0 \%$ is recommended. Also, an average slurry $\mathrm{pH}$ that is lower than 7.8 but above 7.0 was found to favour biogas production.

\section{Conclusion}

The hallmark of this work is the identification of the optimum organic loading rate for effective and efficient recovery of bio-energy from organic wastes especially cow dung whose management has hitherto posed an enormous challenge to waste disposal authorities in most developing countries, including Nigeria as can be observed from Fig. 3A. With this increase in efficiency of harnessing the energy incentive in the use of biomass technology coupled with other benefits of this technology which include its eco-friendliness, there is no 
doubt that if embraced it will go a long way in helping mankind mitigate the twin challenge of a sustainable environment and inadequate energy it is currently facing while promoting food security by closing the gap in the cycle of food production and waste generation.

\section{Recommendation}

It is recommended that in areas that face the challenge of inadequate water supply, the OLR of $38.38 \mathrm{~g}$ $\mathrm{TS} \mathrm{L}^{-1}$ of slurry used in bioreactor 4 is most appropriate.

Finally, to ensure that this technology is fully embraced, especially by the rural poor among whom this technology will most definitely have the greatest impact, it is important that ample research be carried out to find very affordable ways of making these bioreactor available to these rural poor without compromising efficiency. It is recommended that materials like fiber glass and other cheap materials be used as building materials for these bioreactors. However, this needs more research.

\section{Acknowledgement}

We are grateful to the National Centre for Energy Research and Development, University of Nigeria, Nsukka for their support.

\section{References}

[1]. D.S. Chianese, C.A. Rotz, and T.L. Richard, Simulating Methane Emissions from Dairy Farms, American Society of Agricultural and Biological Engineers (ASABE), St. Joseph, MI. 2008, Paper No. 084098.

[2]. T. Al Seadi, D. Rutz, H. Prassl, M. Köttner, T. Finsterwalder, S. Volk, and R. Janssen, Biogas Handbook (University of Southern Denmark: Esbjerg, Niels Bohrs Vej 9 - 10, DK - 6700 Esbjerg, Denmark, 2008)

[3]. L.T. Angenent, K. Karim, M.H. Al-Dahhan, B.A. Wrenn, and R. Domiguez-Espinosa, Production of bioenergy and biochemicals from industrial and agricultural wastewater. Trends in Biotechnology, 22, 2004, 477-485.

[4]. E. Salminen, and J. Rintala, Anaerobic digestion of organic solid poultry slaughterhouse waste - A review. Bioresource Technology, 83, 2002, 13-26.

[5]. R. Alvarez, S. Villca, and G. Lidén, Biogas production from llama and cow manure at high altitude. Biomass and Bioenergy, 30, 2006, 66-75.

[6]. H.M. El-Mashad, G. Zeeman, W.K.P. van Loon, G.P.A. Bot and G. Lettinga, Effect of temperature and temperature fluctuation on thermophilic anaerobic digestion of cattle manure. Bioresource Technology, 95, 2004, 191-201.

[7]. A. Keshtkar, H. Ghaforian, G. Abolhamd, and B. Meyssami, Dynamic simulation of cyclic batch anaerobic digestion of cattle manure. Bioresource Technology, 80, 2001, 9-17.

[8]. S. Uludag-Demirer, G.N. Demirer, C. Frear, and S. Chen, Anaerobic digestion of dairy manure with enhanced ammonia removal. Journal of Environmental Management, 86, 2008, 193-200.

[9]. M.H. Gerardi, The Microbiology of Anaerobic Digesters (Hoboken, New Jersey : John Wiley \&Sons, Inc., 2003).

[10]. 10. E.C. Okoroigwe and S.N. Agbo, Gas Evacuation Effect on the Quantity of Gas Production in a Biogas Digester. Trends in Applied Sciences Research, 2(3), 2007, 246 - 250.

[11]. L.T. Angenent, S. Sung, and L. Raskin, Methogenic population dynamics during startup of full-scale anaerobic sequencing batch reactor treating swine waste. Waste Research, 36, 2002, 4648 - 4654.

[12]. B.P. Kelleher, J.J. Leahy, A.M. Henihan, T.F. O’Dwyer, D. Sutton, and M.J. Leahy, Advances in poultry litter disposal technology A review. Bioresource Technology, 83, 2002, 27-36.

[13]. R.E. Speece, Anaerobic Biotechnology for Industrial Wastewaters (Nashville, TN: Archie Press, 1996)

[14]. V.E. Munch, J. Keller, P. Lant and R. Newell, Mathematical modeling of prefermenters-I. Model development and verification. Water Research, 33, 1999, 2757-2768.

[15]. A. O. A. C. Official Method of Analysis: Association of Analytical Chemists $14^{\text {th }}$ Edition. (Washington, USA: A.O.A.C., 1990).

[16]. D. Pearson, The chemical analysis of food 7th Edition (New York: Churchill Livingstone, 1976)

[17]. A. Walkey and L.A. Black, An examination of Degtjareff method for determining soil organic matter and proposed chromic acid titration method. Journal of Soil Science, 37, 1934, 29 - 38.

[18]. P.J. Meynell, Methane: Planning a digester (Stable Court, Clarington Dorset: Prison Press, 1982)

[19]. S.E. Ogbeide, Biogas from oil mill effluent. Nigerian Journal of Solar Energy, 5, 1988, 8- 13.

[20]. C. Kanu, Biogas from oil mill effluent. Nigerian Journal of Biotechnology, 6, 1988, 90 - 96.

[21]. J.I. Eze, C.D. Ogbonnia, E.O. Uzodinma, and N.F. Oparaku, Application of metal biogas digesters for biogas production. Nigerian Journal of Solar Energy, 19 (2), 2008, $20-23$.

[22]. Bardiya, N. and Gaur, A.C. (1997). Effects of carbon and nitrogen ratio on rice straw biomethanation. Journal of Rural Energy, 4 (1-4), 1-16.

[23]. R.K. Malik, R. Singh, R. and P. Tauro, Effect of inorganic supplementation on biogas production. Biological Wastes, 21 (2), 1987, $139-142$.

[24]. A. Dennis and P.E. Burke, Dairy waste anaerobic digestion handbook: Options for recovering beneficial products from dairy manure (6007 Hill Street, Olympia, WA: Environmental Energy Company, 2001)

[25]. I.S Eze, O.U. Anyanwu, O.U Oparaku and C.O.B. Okoye, Animal manure: A resource or a waste, The $37^{\text {th }}$ Annual Conference of the Nigerian Society of Engineers, 2007, 1-7.

[26]. US EPA, Industrial waste treatment training programme: A field study, Second Edition (United States Environmental Protection Agency, 2001)

[27]. GTZ, Biogas Basics. Biogas Digest, 1999, vol I. 